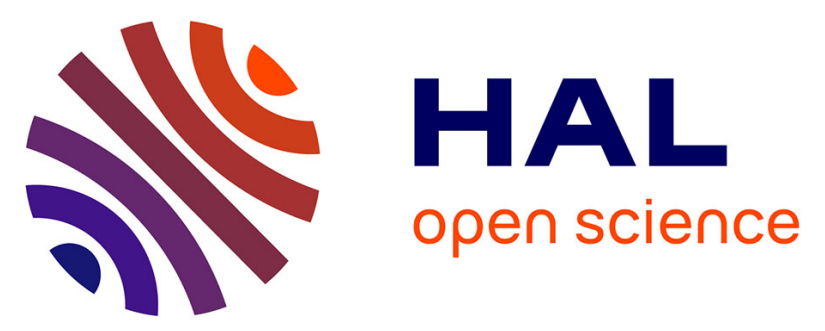

\title{
Semen quality of honey bee drones maintained from emergence to sexual maturity under laboratory, semi-field and field conditions
}

Faten Abdelkader, Guillaume Kairo, Sylvie Tchamitchian, Marianne Cousin, Jaques Senechal, Didier Crauser, Jean Vermandere, Cédric Alaux, Yves Conte, Luc Belzunces, et al.

\section{To cite this version:}

Faten Abdelkader, Guillaume Kairo, Sylvie Tchamitchian, Marianne Cousin, Jaques Senechal, et al.. Semen quality of honey bee drones maintained from emergence to sexual maturity under laboratory, semi-field and field conditions. Apidologie, 2014, 45 (2), pp.215-223. 10.1007/s13592-013-0240-7 . hal-01234717

\section{HAL Id: hal-01234717 https://hal.science/hal-01234717}

Submitted on 27 Nov 2015

HAL is a multi-disciplinary open access archive for the deposit and dissemination of scientific research documents, whether they are published or not. The documents may come from teaching and research institutions in France or abroad, or from public or private research centers.
L'archive ouverte pluridisciplinaire HAL, est destinée au dépôt et à la diffusion de documents scientifiques de niveau recherche, publiés ou non, émanant des établissements d'enseignement et de recherche français ou étrangers, des laboratoires publics ou privés. 


\title{
Semen quality of honey bee drones maintained from emergence to sexual maturity under laboratory, semi-field and field conditions
}

\author{
Faten Ben AbdelKader ${ }^{1,2}$, Guillaume KaIro ${ }^{1}$, Sylvie TCHAmitchian ${ }^{1}$, \\ Marianne Cousin ${ }^{1}$, Jaques Senechal ${ }^{1}$, Didier Crauser ${ }^{1}$, Jean Paul Vermandere ${ }^{1}$, \\ Cédric Alaux ${ }^{1}$, Yves Le Conte ${ }^{1}$, Luc P. Belzunces ${ }^{1}$, Naima Barbouche ${ }^{2}$, \\ Jean-Luc BRUNET ${ }^{1}$ \\ ${ }^{1}$ INRA, UR 406 Abeilles et Environnement, Site Agroparc CS 40509, 84914, Avignon, France \\ ${ }^{2}$ Institut National Agronomique de Tunisie, Laboratoire de Zoologie et d'Apiculture, 1082, Tunis, Tunisia
}

Received 18 January 2013 - Revised 9 July 2013 - Accepted 5 September 2013

\begin{abstract}
In order to evaluate the semen quality among honey bee populations, emergent honey bee drones were maintained to sexual maturity for 20 days under laboratory, semi-field, and field conditions. The drones were successfully maintained in laboratory conditions. Drones under laboratory and field conditions presented a lower spermatozoa concentration and lower protein content than those under semi-field conditions. The viability of spermatozoa was higher under laboratory conditions, and the ATP content and the superoxide dismutase activity were higher both under laboratory and field conditions compared to drones kept under semifield conditions. Hence, our data indicate that the semen quality was similar in drones maintained under laboratory and field conditions.
\end{abstract}

honey bee drones / sexual maturity / fertility / semen quality / sperm

\section{INTRODUCTION}

Insect pollination is both an ecosystem service and a major contributor to crop production all over the world. Indeed, around $80 \%$ of flowering plants are entomophilous, i.e., dependent on insect pollination to reproduce, and it is estimated that half of the pollinators of tropical plants are bees (Bradbear 2009). The pollinating efficiency of honey bees in agricultural landscapes is due to their large num-

Faten Ben Abdelkader and Guillaume Kairo contributed equally.

Corresponding author: J. Brunet, jean-luc.brunet@avignon.inra.fr Manuscript editor: David Tarpy bers, their anatomy and their foraging behavior on only one plant species at one time (Bradbear 2009). However, the abundance and diversity of wild bees are now declining (Biesmeijer et al. 2006) and severe worldwide honey bee losses have been observed (Neumann and Carreck 2010). This could dramatically affect world food safety since the agricultural dependence on pollinators is continuously increasing (Aizen and Harder 2009).

Among the numerous factors that can affect honey bee colonies, a poor queen quality is often reported (van Engelsdorp and Meixner 2010). Since the queen is the sole reproductive female in the colony (laying around 1,000 eggs per day), any stress factor that affects its reproductive output can compromise the colony fate. The queen mates with 
an average of 12 drones (Rhodes 2002) and receives about 6 million spermatozoa into its oviducts from each male (Kerr et al. 1962). Approximately 5.5 million are transported to the spermatheca by active and passive mechanisms over a period of $40 \mathrm{~h}$ (Laidlaw and Page 1984). The post-mating changes are characterized by a new behavior (remain in the colony), physiology (lay around 1,000 eggs per day), and interactions with workers (grooming, feeding, courtship). However, the level and the quality of these post-mating changes can be affected by insemination quantity (Richard et al. 2007). Indeed, poorly inseminated queens produced a different mandibular gland chemical profile and are less attractive to workers. Thus, the frequency of queen loss in feral and commercial honey bee colonies might be influenced by spermathecal sperm depletion (Severson and Erickson 1989) and by queen reproductive status, i.e., egg-laying potential (Moretto et al. 2004), which might depend on drone availability and fertility.

However, little is known about factors that can affect drone fertility and the potential impact it can have on queen mating and colony fate. The main reason is that studying drones is a highly complicated task that since (1) in temperate regions, drones are found in honey bee colonies only during part of the summer season and their availability for studies is therefore limited to a short period of the year, (2) drone larvae can be easily reared outside the colony up to prepupal or pupal stage (Woyke 1969) but adult rearing in artificial conditions is a major challenge. In addition, the age at which drones mature and are able to mate with queens is not known with accuracy because of difficulties to assess it under field conditions. Rhodes (2002) stated that drones are mature at about 16 days of age and become less efficient for mating after 28 days (of age) but Moritz (1989) found that, 12-day-old drones are mature and their sperm may be used for queen insemination. The time required for drones to reach sexual maturity also depends on their genetics (Rhodes et al. 2010). Besides, many factors can affect the maturation process of drones such as the diet since an abundant and continuous source of pollen and proteins are necessary for sperm production (Cobey 1983). Therefore, de- veloping methods for maintaining emergent drones under controlled conditions would help to better understand their biology and the factors that can modify their sexual maturation and fertility.

In this study, we succeeded to maintain emergent drones until sexual maturity under various conditions (laboratory, field, and semifield) and compared the effect of these conditions on drone semen quality and quantity. Semi-field conditions represent a way to be in more natural conditions (close to the field conditions) but with the possibility to control some parameters, which would be impossible in the field. To standardize procedure of sperm maturation, we compared number, viability and energetic state of spermatozoa, the activity of superoxide dismutase (SOD), which is an enzyme that protects cells against damages caused by superoxide anion $\mathrm{O}_{2}{ }^{-}$, the most common free radical, and the level of proteins in semen, which play a role in male reproductive success by improving sperm competitive ability and modifying female behavior as shown in Drosophila (Findlay et al. 2008).

\section{MATERIALS AND METHODS}

All chemicals and reagents were purchased from Sigma Chemical (Saint Quentin Fallavier, France). Luminescence and absorbance were measured using a TECAN infinite ${ }^{\circledR}$ F500 plate reader.

\subsection{Drone rearing}

Experiments were performed in Avignon (France) on June 2011 with Apis mellifera L. colonies. To stimulate drone production, drone combs were introduced in 10 strong colonies ( 1 comb/colony). These colonies were treated with Amitraz in September 2010 to control Varroa population. The day before emergence, brood frames were placed into an incubator in the dark at $34{ }^{\circ} \mathrm{C}$ and $70 \%$ relative humidity. Drones were considered mature if they could ejaculate when they are stimulated.

\subsubsection{Laboratory conditions}

Three large cages $(42.5 \times 30 \times 55 \mathrm{~cm} ; \mathrm{L} \times \mathrm{W} \times \mathrm{h})$ based on the design of Pain cages (Pain 1966) were 
used to keep emergent drones in laboratory conditions (Figure 1). These cages were placed in a rearing room at $33 \pm 1{ }^{\circ} \mathrm{C}$ and $60 \pm 10 \%$ humidity with $2 \mathrm{~h}$ /day lighting. Three wax combs were $(13 \times 40 \mathrm{~cm} ; \mathrm{w} \times \mathrm{L})$ attached to the top wall of each cage and spaced from each other by $3 \mathrm{~cm}$. To mimic the hive environment, a Beeboost ${ }^{\circledR}$ (Pherotech) releasing a queen mandibular pheromone was placed in each cage. To maintain the hygiene of the cages, a filter paper was deposed on a removable floor and replaced every 2 days. To give more space to drones for flying, the surface of the removable floor was brought down by $3 \mathrm{~cm}$ every 2 days. Bees were fed with $50 \%(w / v)$ sucrose syrup for $10 \mathrm{~h} /$ day (for possible treatments which are not reported here) and ad libitum with candy (Apifonda ${ }^{\circledR}$ ), water, and pollen for the remaining $14 \mathrm{~h}$. The food was contained in $15 \mathrm{~mL}$ Falcon ${ }^{\mathrm{TM}}$ tubes placed on both sides of the cage.

Drones have lower direct pollen consumption and digestive enzyme levels in the gastrointestinal tract than workers, although their nutrient needs are quite high. However, the workers provide them with predigested food, via proteinaceous glandular secretions

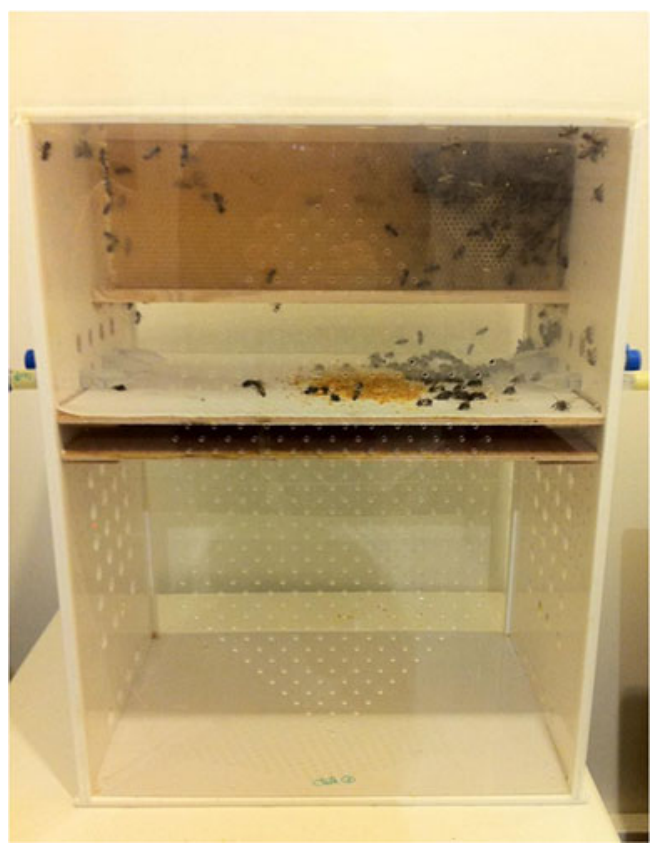

Figure 1. Cage designed to maintain drones under laboratory conditions. and honey (Hrassnigg and Crailsheim 2005). Therefore, 200 emerging drones were introduced in each cage along with 1,000 emerging workers. The behavior of drones and workers was observed regularly to see whether the drones were accepted or rejected by the workers.

\subsubsection{Semi-field conditions}

Four queenless nuclei of 5,000 honey bees were placed under an outdoor tunnel covered with an insect proof mesh. Three hundred emerging drones were introduced in each nucleus. Each nucleus contained four empty frames, one worker brood frame, an empty box placed above the frames to give space for drones to move and a queen excluder under the hive body to prevent the exit of drones. No food was supplied inside the nuclei. The honey bee nuclei were introduced in the tunnel three days before drone introduction to get bees used to visit the feeder placed on a table at equal distance from the nuclei. This feeder consisted of a yellow cup containing the sucrose solution. A piece of cork and filter paper were placed on the surface of sucrose solution to enable the honey bees to land. To avoid overexposure to the sun, umbrellas were placed above each beehive. Honey bees received $50 \%(w / v)$ sugar syrup from 9:00 to 12:00 a.m. each day. Outside this period, honey bees received water and pollen ad libitum.

\subsubsection{Field conditions}

Three hives were used in this test and 1,000 colormarked drones were confined into each hive. To prevent the loss of drones, a queen excluder was placed between the brood chamber and bottom board and a second queen excluder placed on top of the brood chamber beneath the upper box. The number of bees in each hive was estimated to $20,000-25,000$ by weighting five frames out of ten with and without the bees.

\subsection{Semen collection}

For each condition, drone semen was collected after 20 days. Semen was collected by a manual eversion. In brief, drones of a known age were stimulated to ejaculate 
by pressing on the thorax, which usually resulted in eversion of the endophallus. Semen was collected from the tip of the endophallus, with a glass capillary connected to a syringe filled with Kiev solution $(36 \mathrm{~g} / \mathrm{L}$ trisodium citrate, $3.6 \mathrm{~g} / \mathrm{L}$ sodium bicarbonate, $0.6 \mathrm{~g} / \mathrm{L}$ potassium chloride, $5 \mathrm{~g} / \mathrm{L}$ glucose, $3 \mathrm{~g} / \mathrm{L}$ sulfanilamide, $\mathrm{pH} 8.5$, osmotic pressure $=486 \mathrm{mOs} / \mathrm{ml}$ ).

We pooled semen from different drones for each group to obtain $50 \mu \mathrm{l}$ of semen that was required for the different analysis. We had three pools in laboratory and field conditions and four pools in semi-fields conditions obtained from about 80-100 drone per each pool. We calculated an average volume of ejaculate per drone and it was $0.76 \pm 0.17 \mu \mathrm{L} /$ drone.

\subsubsection{Spermatozoa concentration}

The semen was diluted $(1: 200)$ in the Kiev solution and spermatozoa were counted $(15 \mu \mathrm{L}$ of diluted semen) under a phase contrast microscope by using a Malassez cell. The counting of each sample was done by three different persons in order to minimize errors.

\subsubsection{Viability test}

Viability test was performed with a Prestoblue ${ }^{\circledR}$ kit (Invitrogen) which is a resazurin-based solution that functions as a cell viability indicator. Prestoblue ${ }^{\mathrm{TM}}$ reagent is quickly reduced by metabolically active cells, providing a quantitative measure of viability. Samples of diluted semen were put in a 96-white-well microplate. Each well contained $90 \mu \mathrm{L}$ of diluted semen containing 2 million spermatozoa and $10 \mu \mathrm{L}$ of Prestoblue $^{\circledR}$. The microplate was kept in obscurity for $10 \mathrm{~min}$ before measuring the absorbance at $570 \mathrm{~nm}$ according to the recommendations of the manufacturer.

\subsubsection{ATP content}

ATP content was performed with ATPlite ${ }^{\circledR}$ kit (PerkinElmer) in the same wells as the viability test. The ATPLite ${ }^{\circledR}$ assay system is based on the production of light caused by the reaction of ATP with added luciferase and D-luciferin. The emitted light is proportional to the ATP concentration within certain limits. For this, $50 \mu \mathrm{L}$ of a mammalian cell lysis solution (PerkinElmer) were added to the $100 \mu \mathrm{L}$ of diluted semen containing 2 millions spermatozoa in each well and the whole microplaque was covered and shaken gently for $5 \mathrm{~min}$ with an orbital shaker at $700 \mathrm{rpm}$. Then, $50 \mu \mathrm{L}$ of substrate solution was added, the microplaque was covered and shaken for $5 \mathrm{~min}$ at $700 \mathrm{rpm}$ and the microplaque was kept in the darkness for $10 \mathrm{~min}$ before measuring the luminescence intensity (LI) and measured by the Tecan plate reader.

\subsubsection{SOD activity}

Superoxide dismutase that catalyzes the dismutation of the superoxide anion $\left(\mathrm{O}_{2}{ }^{-}\right)$into hydrogen peroxide $\left(\mathrm{H}_{2} \mathrm{O}_{2}\right)$ and molecular oxygen $\left(\mathrm{O}_{2}\right)$, provides an important defense against cell oxidative damage. In the SOD assays, superoxide ions were generated from the conversion of xanthine and $\mathrm{O}_{2}$ to uric acid and $\mathrm{H}_{2} \mathrm{O}_{2}$ by xanthine oxidase (XOD). The superoxide anion then converted a tetrazolium salt into a formazan dye. The addition of SOD to this reaction reduces superoxide ion levels, thereby lowering the rate of formazan dye formation. SOD activity of the experimental sample was measured as the percent inhibition of the rate of formazan dye formation. The assay mixture contained $0.1 \mathrm{mM}$ ethylenediaminetetraacetic acid (EDTA), $0.025 \mathrm{mM}$ nitro blue tetrazolium (NBT) $0.1 \mathrm{mM}$ xanthine and $50 \mathrm{mM}$ phosphate/carbonate buffer ( $\mathrm{pH}$ 7.8). The sperm volume corresponding to 2 million spermatozoa was adjusted to $90 \mu \mathrm{L}$ with Kiev medium and centrifuged at $1,200 \times \mathrm{g}$ for $10 \mathrm{~min}$ at $23{ }^{\circ} \mathrm{C}$. Ten microliters of supernatant containing seminal plasma was added to the assay medium. To start the reaction $20 \mu \mathrm{L}$ of xanthine oxidase (1.4 U/mg proteins) were added. SOD activity was spectrophotometrically measured during $5 \mathrm{~min}$ at $560 \mathrm{~nm}$.

\subsubsection{Protein assay}

Proteins were assayed with the Bio-Rad protein assay ${ }^{\circledR}$ according to the method of Bradford (Bradford 1976). The assay medium contained $5 \mu \mathrm{L}$ of appropriately diluted semen, $40 \mu \mathrm{L}$ of Coomassie brilliant blue $\mathrm{G}-250$ and $155 \mu \mathrm{L}$ of $\mathrm{H}_{2} \mathrm{O}$. The microplaque was kept in darkness for $20 \mathrm{~min}$. Absorbance was read at $595 \mathrm{~nm}$. 


\subsubsection{Statistics}

The effects of conditions on semen quality (spermatozoa number, spermatozoa vitality, ATP and protein content and SOD activity) were assessed using the Wilcoxon Signed-Rank Test.

\section{RESULTS}

\subsection{Drone behavior in laboratory conditions}

Despite being maintained in artificial conditions in a large laboratory cage, bees did not exhibit any abnormal behavior. From the introduction in the cages, the emergent bees (workers and drones) took refuge between the wax frames and workers start quickly building the cells to store food. During the first days, workers and drones stood on the wax. Some workers moved to get pollen on the filter paper. The consumption of sucrose syrup was higher in the first days in all cages (data not shown). During cage maintenance, an important flying activity of drones was detected following the exposure to the light but it was decreased after $20 \mathrm{~min}$. In laboratory conditions, emerged drones introduced inside cages were successfully accepted.

\subsection{Semen quality}

\subsubsection{Concentration and viability of drone spermatozoa}

Drones maintained under artificial (laboratory) conditions had a lower concentration of spermatozoa $\left(2.5 \pm 0.1 \times 10^{6} \mathrm{spz} / \mu \mathrm{L}\right.$ semen $)$ than drones maintained under semi-field conditions $(3.4 \pm 0.4 \times$ $10^{6} / \mu \mathrm{L}$ semen $)(P=0.03$, Figure $2 \mathrm{a})$. However, the concentration of spermatozoa produced by drones in field $\left(2.2 \pm 0.6 \times 10^{6} \mathrm{spz} / \mu \mathrm{L}\right.$ of semen $)$ and laboratory conditions was not different $(P=0.25)$.

No difference was found in spermatozoa viability in semi-field and field conditions $(P=$ 0.11 , Figure $2 b$ ). However, drones produced spermatozoa with a higher viability in laboratory conditions (34 and $38 \%$ higher than drones maintained under semi-field and field conditions $(P<0.001, P<0.001$, respectively $))$.

\subsubsection{ATP content and SOD activity}

ATP content and SOD activity in semen of drones maintained under laboratory and field conditions were not different but higher than semen of drones maintained under semi-field conditions $(P=0.9, P=0.016, P=0.017$, Figure $3 \mathrm{a}$, and $P=0.05, P<0.01, P<0.01$ Figure 3b).

\subsubsection{Protein content}

Protein content in seminal plasma of drones maintained under semi-field conditions was 27
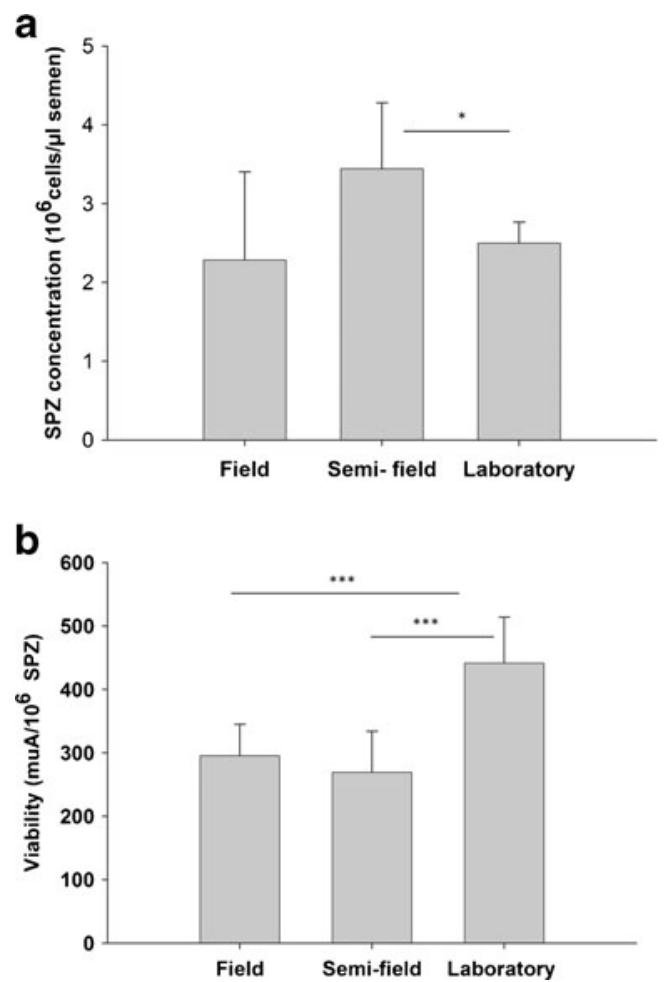

Figure 2. Concentration and viability of drone spermatozoa. The (a) concentration and (b) viability of spermatozoa (SPZ) expressed in milliunits of absorbance (muA) in the semen was determined in drones kept during 20 days under field, semi-field, and laboratory conditions. Semen was collected and spermatozoa were counted the same day. $*$ and $* * *$ indicates significant differences at $P<0.05$ and $P<$ 0.001 respectively. Data corresponded to means \pm S.D. 
and $50 \%$ higher than in drones maintained under field and laboratory conditions $(P=0.03$, $P<0.001)$ respectively (Figure 4$)$. In addition, protein content in seminal plasma of drones was higher under field conditions than under laboratory conditions $(P<0.001)$.

\section{DISCUSSION}

A large part of the literature deal with drone breeding under field conditions where the drones are kept in their colonies. Woyke (1969) presented a method of drone larvae rearing in laboratory but just until prepupal stage. Here, we showed for the
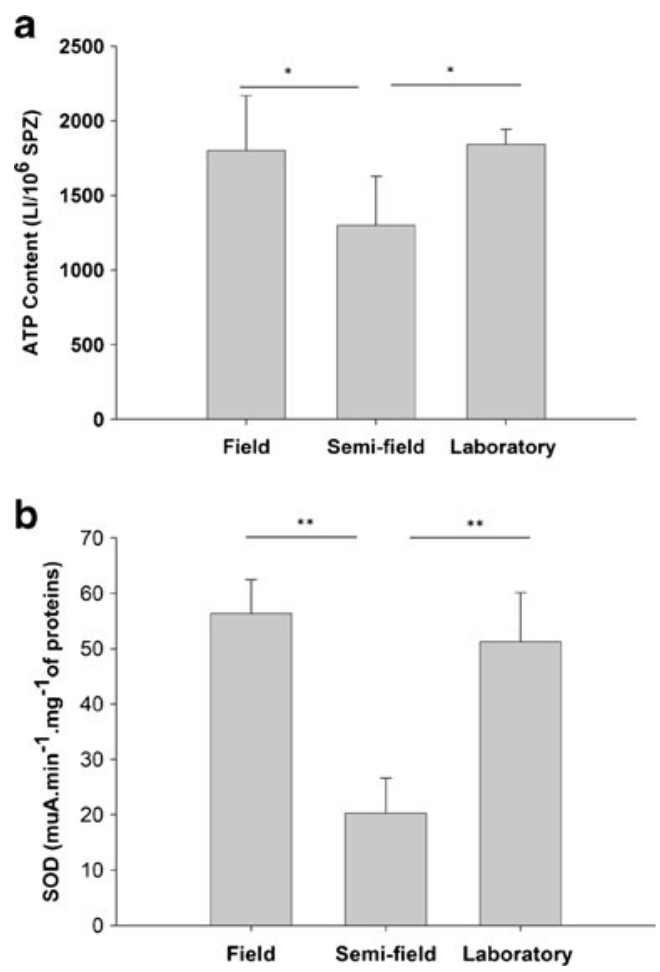

Figure 3. ATP content and SOD activity in drone semen. The (a) ATP content expressed in luminescence intensity (LI) and (b) SOD specific activity (AS) is expressed in milliunits of absorbance per minute per milligram of proteins (muA min ${ }^{-1} \mathrm{mg}^{-1}$ of proteins) are determined in semen of drones kept during 20 days under field, semi-field, and laboratory conditions. ${ }^{*}$ and ** indicates significant differences at $P<0.05$ and $P<$ 0.01 , respectively. Data corresponded to means \pm S.D. first time that emergent drones can be kept in laboratory cage and in semi-field conditions for at least 20 days. These drones were kept until maturity and then analyses on sperm quality could be performed.

A major component of queen longevity is the concentration of sperm cells stored in the spermatheca (Cobey 2007). Spermatozoa concentration is regarded as a basis for understanding several aspects of biology of honey bee mating, including drone fitness, polyandry and sperm competition (Koeniger et al. 2005). The spermatozoa concentration produced per drone in our study (2.2-3.4× $10^{6} / \mu \mathrm{L}$ semen) was lower than that found by Rhodes et al. (2010) $\left(3.33 \times 10^{6} / \mu \mathrm{L}\right.$ semen). In other studies, the concentration of spermatozoa was much higher (Collins and Pettis 2001, 8.66× $10^{6}$; Schlüs et al. $\left.2003,11.9 \times 10^{6}\right)$. The discrepancy between sperm counts from different studies may be due to differences in the counting method. In the previous works, the sperm number was determined in seminal vesicles, whereas in our study, sperm was counted in semen released at the tip of the endophallus following manual eversion. Regarding our study, the variation in sperm concentration between drones kept under the field, semi-field and laboratory conditions can be due to the conditions before semen collection. In fact, Bieńkowska et al. (2011) found that the higher and lower temperatures at which the drones were kept before semen collection had a significant impact on the total number of spermatozoa.

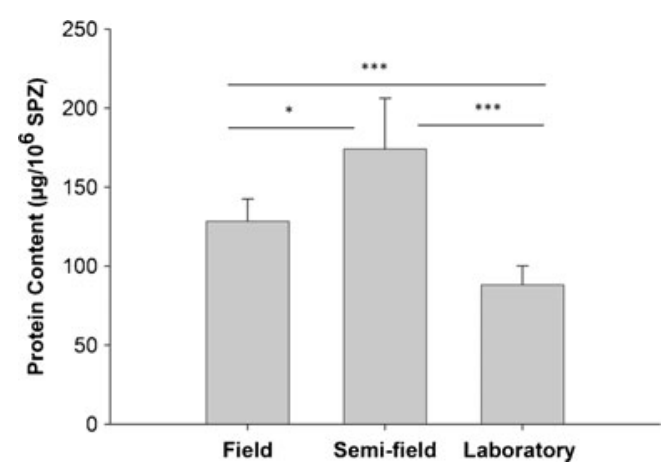

Figure 4. Protein content in drone semen. $*$ and $* * *$ indicate significant differences at $P<0.05$ and $P<0.001$, respectively. Data corresponded to means \pm S.D. 
A sperm viability test is a common assay to assess the quality of drone semen. Locke and Peng (1993) found that the sperm viability decreases with drone age. For example, they observed lower sperm viability in 4- and 6week-old drones compared to 2-week-old but fully matured drones. In our experiments, we found that 2-week-old drones were not matured yet (data not shown) because they did not ejaculate. Furthermore, the physical and chemical properties of diluents $(\mathrm{pH}$, osmolarity, and nutrients) and the handling methods can influence sperm cell survival (Verma 1978; Moritz 1984; Collins 2000). All experimental analysis being equal (20-day-old drones and same diluent), our results showed that drones kept under laboratory conditions present higher sperm viability than those kept under field and semi-field conditions.

Adenosine triphosphate (ATP) is the main energy source used by the sperm flagellum to initiate motility (Du Toit et al. 1993). Our results showed that spermatozoa of drones maintained under laboratory and field conditions present similar ATP content, which was lower in drones maintained under semi-field conditions. Froman and Feltmann (1998) reported that sperm cell motion depends on the physical environment, temperature, chemical environment, metabolic capacity, and structural integrity of the cells. In fact, oxidative stress, via the production of reactive oxygen species, has been shown to cause membrane deterioration, resulting in ATP depletion and decreased sperm movements (Gogol et al. 2009). Thus, we can hypothesize that spermatozoa of drones maintained in semi-field conditions could be more exposed to oxidative stress contrary to spermatozoa of drones maintained under laboratory and field conditions.

Superoxide dismutase is one of the antioxidant enzymes involved in the survival of drone spermatozoa (Wegener et al. 2012). SOD level has an essential role in maintaining the balance between reactive oxygen species (ROS) generation and degradation (Gavella et al. 1996). Kurpisz et al. (1996) demonstrated that SOD activity has a beneficial impact on sperm movement, which depends on the dynein ATPase that hydrolyzes ATP to produce a flagellar beat. Our results showed significantly lower semen SOD activity and ATP content in drones maintained under semi-field conditions compared to the semen of drones maintained under field and laboratory conditions (Figure 3). However, when looking at the spermatozoa viability, spermatozoa of drones maintained under semi-field and field conditions presented the same rates of spermatozoa viability. The lower SOD level found in semen of drones maintained under semi-field conditions suggests that spermatozoa obtained under these conditions could undergo oxidative injuries which are normally limited by the activity of SOD isoenzymes (Johnson and Giulivi 2005). This is consistent with the work of Moretto et al. (2004) that shows that the tunnel environment induces immune-depression and reduces the potential to detoxify ROS and thus imposes the honey bee with an oxidative stress.

The presence of proteins in the seminal fluid is required for sperm viability (Avila et al. 2011). Fifty seven proteins were detected in the seminal fluid of honey bee (Baer et al. 2009). Some have known or predicted roles in maintaining sperm viability either by providing the sperm with its physiological needs, by protecting it from microbial attacks or by reducing oxidative stress in the sperm. The higher protein content found in semen of drones maintained under semi-field conditions could be explained by an organism response to injuries in order to protect spermatozoa through synthesis of antioxidant defense proteins and metal-binding proteins (King et al. 2011) where SOD was expressed.

\section{CONCLUSION}

This work describes two different methods (laboratory and semi-field) to obtain drones for studying the modulation of drone fertility by biotic and abiotic stressors based on artificial maintain. The laboratory method was especially useful to obtain fertile honey bee drones with a semen quality comparable to those of drones kept under field conditions. This could be useful for testing the effects of pesticides and/or pathogens on drone 
quality. This method in laboratory conditions can be especially useful for scientists and queen breeders who are facing many difficulties when they rear drones to provide good semen quality in quantity with standardized processes. In conclusion, those results open new perspectives in the development of drone breeding and fertility studies and in the assessment of the possible impacts of different stressors on the reproduction.

\section{ACKNOWLEDGMENTS}

This work was supported in part by FranceAgrimer (FEAGA project 11-42R) and by Agence Universitaire de la Francophonie (AUF).

Qualité du sperme de mâles d'abeilles maintenus, de l'émergence à la maturité sexuelle, en laboratoire, en conditions semi-naturelles ou de terrain

Mâle / Apis mellifera / maturité sexuelle / fertilité / sperme / qualité du sperme

Samenqualität von Honigbienen-Drohnen, die vom Schlupf bis zur Geschlechtsreife unter Laborbedingungen, Halbfreiland- bzw. Freilandbedingungen gehalten wurden

\section{Honigbienen-Drohnen / Samenqualität / Spermien / Geschlechtsreife / Fertilität}

\section{REFERENCES}

Aizen, M.A., Harder, L.D. (2009) The global stock of domesticated honey bees is growing slower than agricultural demand for pollination. Curr. Biol. 19(11), 915-918

Avila, F.W., Sirot, L.K., LaFlamme, B.A., Rubinstein, C.D., Wolfner, M.F. (2011) Insect seminal fluid proteins: identification and function. Annu. Rev. Entomol. 56(1), 21-40

Baer, B., Heazlewood, J.L., Taylor, N.L., Eubel, H., Millar, A.H. (2009) The seminal fluid proteome of the honeybee Apis mellifera. Proteomics 9(8), 20852097

Bieńkowska, M., Panasiuk, B., Węgrzynowicz, P., Gerula, D. (2011) The effect of different thermal conditions on drone semen quality and number of spermatozoa entering the spermatheca of queen bee. J. Apic. Res. 55(2), 161-168

Biesmeijer, J.C., Roberts, S.P.M., Reemer, M., Ohlemüller, R., Edwards, M., et al. (2006) Parallel declines in pollinators and insect-pollinated plants in Britain and the Netherlands. Science 313(5785), 351-354

Bradbear, N., Food and Agriculture Organization of the United Nations, et al. (2009). Bees and their role in forest livelihoods: a guide to the services provided by bees and the sustainable harvesting, processing and marketing of their products. Food and Agriculture Organization of the United Nations, Rome

Bradford, M.M. (1976) A rapid and sensitive method for the quantitation of microgram quantities of protein utilizing the principle of protein-dye binding. Anal. Biochem. 72, 248-254

Cobey, S. (1983) Drone rearing for instrumental insemination. III. Am. Bee. J. 123(4), 284-289

Cobey, S.W. (2007) Comparison studies of instrumentally inseminated and naturally mated honey bee queens and factors affecting their performance. Apidologie 38(4), 390-410

Collins, A.M. (2000) Relationship between semen quality and performance of instrumentally inseminated honey bee queens. Apidologie 31(3), 421429

Collins, A.M., Pettis, J.S. (2001) Effect of Varroa infestation on semen quality. Am. Bee. J. 141(8), 590-593

Du Toit, D., Bornman, M.S., Van Der Merwe, M.P., Du Plessis, D.J., Oosthuizen, J.M. (1993) Differential sperm motility scoring and sperm ATP concentrations. Arch. Androl. 30(1), 69-71

Findlay, G.D., Yi, X., MacCoss, M.J., Swanson, W.J. (2008) Proteomics reveals novel Drosophila seminal fluid proteins transferred at mating. PLoS Biol. 6(7), e178

Froman, D.P., Feltmann, A.J. (1998) Sperm mobility: a quantitative trait of the domestic fowl (Gallus domesticus). Biol. Reprod. 58(2), 379-384

Gavella, M., Lipovac, V., Vucic, M., Rocic, B. (1996) Relationship of sperm superoxide dismutase-like activity with other sperm-specific enzymes and experimentally induced lipid peroxidation in infertile men. Andrologia 28(4), 223-229

Gogol, P., Szczesniak-Fabianczyk, B., WierzchosHilczer, A. (2009) The photon emission, ATP level and motility of boar spermatozoa during liquid storage. Reprod. Biol. 9(1), 39-49

Hrassnigg, N., Crailsheim, K. (2005) Differences in drone and worker physiology in honeybees (Apis mellifera). Apidologie 36(2), 255-277

Johnson, F., Giulivi, C. (2005) Superoxide dismutases and their impact upon human health. Mol. Asp. Med. 26(4), 340-352 
Kerr, W.E., Zucchi, R., Nakadaira, J.T., Butolo, J.E. (1962) Reproduction in the social bees (Hymenoptera: Apidae). J. N. Y. Entomol. Soc. 265-276

King, M., Eubel, H., Millar, A.H., Baer, B. (2011) Proteins within the seminal fluid are crucial to keep sperm viable in the honeybee Apis mellifera. J. Insect Physiol. 57(3), 409-414

Koeniger, G., Koeniger, N., Tingek, S., Phiancharoen, M. (2005) Variance in spermatozoa number among Apis dorsata drones and among Apis mellifera drones. Apidologie 36(2), 279-284

Kurpisz, M., Miesel, R., Sanocka, D., Jedrzejczak, P. (1996) Seminal plasma can be a predictive factor for male infertility. Hum. Reprod. 11(6), 1223-1226

Laidlaw, H.H., Page, R.E. (1984) Polyandry in honey bees (Apis mellifera L.): sperm utilization and intracolony genetic relationships. Genetics 108(4), 985-997

Locke, S.J., Peng, Y.S. (1993) The effects of drone age, semen storage and contamination on semen quality in the honey bee (Apis mellifera). Physiol. Entomol. 18(2), 144-148

Moretto, G., Guerra, J.C., Kalvelage, H., Espindola, E. (2004) Maternal influence on the acceptance of virgin queens introduced into Africanized honey bee (Apis mellifera) colonies. Genet. Mol. Res. 3(3), 441-445

Moritz, R.F.A. (1984) The effect of different diluents on insemination success in the honeybee using mixed semen. J. Apic. Res. 23(3), 164-167

Moritz, R.F.A. (1989) The Instrumental insemination of the queen bee. APIMONDIA, Bucharest

Neumann, P., Carreck, N.L. (2010) Honey bee colony losses. J. Apic. Res. 49(1), 1-6
Pain, J. (1966) Note technique nouveau modèle de cagettes expérimentales pour le maintien d'abeilles en captivité. Ann. Abeille 9(1), 71-76

Rhodes, J. (2002). Drone honey bees: rearing and maintenance. Agnote DAI 112

Rhodes, J.W., Harden, S., Spooner-Hart, R., Anderson, D.L., Wheen, G. (2010) Effects of age, season and genetics on semen and sperm production in Apis mellifera drones. Apidologie 42(1), 29-38

Richard, F.-J., Tarpy, D.R., Grozinger, C.M. (2007) Effects of insemination quantity on honey bee queen physiology. PLoS One 2(10), e980

Schlüns, H., Schlüns, E.A., Praagh, J.V., Moritz, R.F.A. (2003) Sperm numbers in drone honeybees (Apis mellifera) depend on body size. Apidologie 34(6), 577-584

Severson, D.W., Erickson, E.H. (1989) Seasonal constraints on mating and insemination of queen honey bees in a continental climate. Apidologie 20(1), 2127

van Engelsdorp, D., Meixner, M.D. (2010) A historical review of managed honey bee populations in Europe and the United States and the factors that may affect them. J. Invertebr. Pathol. 103(Suppl 1), 80-95

Verma, L.R. (1978) Biology of honeybee (Apis mellifera L.) spermatozoa. 1. Effect of different diluents on motility and survival. Apidologie 9(3), 167-173

Wegener, J., May, T., Knollmann, U., Kamp, G., Muller, $\mathrm{K}$., et al. (2012) In vivo validation of in vitro quality tests for cryopreserved honey bee semen. Cryobiology 65(2), 126-131

Woyke, J. (1969) A method of rearing diploid drones in a honeybee colony. J. Apic. Res. 8(2), 65-74 